\title{
From command to market-driven economy: the changing role of manufacturing industries in Romania
}

\author{
Claudia Popescu* \\ Bucharest University of Economic Studies E Institute of Geography Romanian Academy, \\ Romania
}

In 1990, Romania and other CEE countries embarked on a political shift that prompted radical structural and spatial changes in economic activities. Industrial restructuring holds a central role in strengthening both EU convergence and internal socioeconomic divergence. The aim of this paper is to discuss the contribution of manufacturing to national wealth creation, the attractiveness of industries to foreign direct investments, and the evolutionary trajectories of manufacturing employment and firms in conjunction with the pathways taken at the level of the national economy. To attain this aim, we analyse in detail the period between 2002 and 2019, looking at the temporal dynamics of the industry in times of growth and crisis. The changes discussed are typical of economic restructuring, with regions and urban centres experiencing a dramatic change in their economic roles and functions and increasing inequalities between metropolitan and non-core regions.

Key Words: industrial activities, structural changes, spatial inequalities, Romania

Article Info: Received: May 15, 2021; Accepted: July 31, 2021; Online: November 30, 2021.

\section{Introduction - context of structural socioeconomic changes in CEE economies}

In 1990 the Central and Eastern European countries (CEE) embarked on a political shift that prompted radical structural and spatial changes in their

\footnotetext{
* Correspondence address

Address: 41 Dacia Blvd, 010404, sector 1, Bucharest

Phone: 004.031.91990/ext 378 | Email: cldpopescu@yahoo.com
}

(C)2021 Human Geographies; The authors

(e) $\stackrel{G}{r}$ This work is licensed under a

Creative Commons Attribution 4.0 International License. DOI:10.5719/hgeo.2021.152.1 
economic activities. The openness of CEE economies and the collapse of the COMECOM (Council for Mutual Economic Assistance, founded in 1949 by the Soviet Union and its satellites) broke down the wall that defended "socialism from the world market" (Negri, 2006:1). These countries have immersed themselves in a hybrid model of capitalism, intending to develop market-driven economies (Rapacki et al., 2020) where multiple still-socialist structures have entangled the space economy (Murawski, 2018) along with the binaries of legacies vs change (Golubchikov, 2016). For most CEE countries, the economic reorganization occurred in the context of European Union (EU) enlargement with a significant impact on economic performance at the local and regional levels (Capello \& Perucca, 2015).

In CEE countries, the focus on industrialisation as a driving force of economic growth during state socialism translated into the central role played by the structural changes of the industrial sector in economic reconfiguration during post-communism (Grillitsch, 2019). The oversized industrial sector in most CEE countries has been subject to downsizing, rationalization, and privatization either through the shock therapy or the hesitant transition. Studies devoted to the deindustrialisation process triggered by demand shifts, increasing productivity and changing trade patterns (Škuflić \& Družić, 2016) aimed at relating the context-specific response to varying inherited structures and different processes of industrial change that explain the economic performance of regions.

The emerging export-oriented economy of CEE (Květoň \& Šafr, 2019) and the need to further export sophistication (Stojčić \& Aralica, 2018) have enforced both the reindustrialisation trends and regional inequalities. More developed regions with greater sectoral variety remodelled their production specialization to higher-value functions while economically backward regions strongly dependent on exports had to overcome their lower innovation potential (Capello \& Perucca, 2017; Květoň \& Šafr, 2019). Regions dominated by large and young exporting and foreign-owned firms passed more smoothly through the crisis of 2008-2010 through employment and investment adjustments than regions where old and small firms prevail (Burger et al., 2017). The successful integration of CEE countries supported mainly by reindustrialization was interrupted by the 2008-2010 economic crisis due to accumulated domestic and external imbalances during the growth period, higher exposure to the reduction of international trade, and economic foundations that we less robust than in the old EU member states (Burger et al., 2017).

Based on either localization economies or agglomeration economies, the question placed at the centre of the scientific debate was related to the role of specialization and diversification on regional growth (Glaeser et al., 1992). Regions vary according to their diversification/specialization characteristics related to the industrial life cycle and agglomeration externalities (Neffke et al., 2008). In addition, the sector-specific industrial dynamics associated with technological level and population and job density differentiate between the core specialized in innovative manufacturing and service sectors and the periphery dependent on traditional production-oriented sectors (Frenken et al., 2015; 
Capasso et al., 2016). Having few production sectors able to support regional growth (Boschma \& Frenken, 2011; Dawley et al. 2014), the old industrial and peripheral regions have to use alternative mechanisms besides agglomeration economies, such as borrowed size and regional embeddedness (Martinus et al., 2020) to trigger development strategies conceptualized in beyond-growth and shrink smart thinking (Leick \& Lang, 2018; Dax \& Fischer, 2018; Kupper et al., 2018).

Geographic proximity to the western European core, large scale urbanization and accessibility largely determined the spatial reconfiguration of manufacturing in western regions, metropolitan areas and transport corridors (Smith \& Timár, 2010; Capello \& Perucca, 2017), reinforcing divergence and polarization along with the core-periphery patterns of economic organization (Kinossian, 2018; Smętkowski, 2018). The production of regional inequalities relies on various drivers, among which the one-size-fits-all EU regional policy, historical legacies leading to administrative recentralization tendencies and regional industrial restructuring play a central role (Raagmaa et al., 2019). In a cross-country analysis at the EU level, Trippl et al. (2020) characterize the less-developed regions, many in CEE countries (Romania, Hungary, Poland, and the Czech Republic), as typically featuring organizational thinness. In these regions, the co-existence of SMEs (small and medium-sized enterprises) with low innovation capabilities and MNEs (multinational enterprises) subsidiaries, externally controlled, hinders the mobilization of actors that would spur innovation and knowledge-based production activities. Both regional capabilities and inter-regional linkages are crucial to determine sectoral diversification, especially in the case of peripheral regions. Although there is solid evidence that relatedness and complexity are mutually-reinforcing mechanisms to support employment growth and regional wealth in large city regions, recent research argues that in smaller economic contexts, these positive effects are not empirically validated (Davies \& Maré, 2021). The factors that contribute to the modernization of regional economies based on diversification in fields with competitive advantage and innovation activities are already identified by previous studies: investments in education, the attraction of research and development knowledge from outside the regions, and intra- and interregional networks of firms (Ferreira et al., 2021). Significant progress was made to set up regional innovation policies, ranging from industrial and technological parks development to cluster initiatives (Hassink \& Gong, 2019). However, the diffusion of new technologies to support the endogenous potential of less developed regions is hampered by a weak cooperation culture between industry and public authorities, poor involvement of private stakeholders, universities and research institutes, and the varying power and governance capacities at the regional level (Trippl et al., 2020). The question that remains open, especially in the case of less developed regions, is how and why the combinations of different factors might explain the success or failure of the development process (Lagendijk et al., 2020; Rutten, 2020).

Within this context of multifaceted and multi-scalar changes, Romania is a relevant example of the radical transformation of manufacturing industries and their role in the national economy. The aim of this paper is to discuss the 
contribution of manufacturing to national wealth creation, the attractiveness of the industry to foreign direct investments (FDI), and the evolutionary trajectories of manufacturing employment and firms in conjunction with the pathways taken the national economy. To attain this aim, the paper analyses in detail the period between 2002 and 2019, looking at the temporal dynamics of the industry in times of growth and crisis. The national level was chosen to obtain a comprehensive view of the changes in manufacturing and the economy and the role of manufacturing therein. The statistical data were collected from the Tempo online series of data released by the National Institute of Statistics (matrices INT101S and INT101H; FOM104A and FOM104E; CON103C and CON103I) and the reports of the National Bank of Romania on direct foreign investments. In line with the research questions, the data were plotted on graphics to visualize the response of manufacturing in terms of GDP creation, volume of FDI, employment and firms to successive waves of reindustrialization and deindustrialization reflected by the change rates on year by year basis. Consequently, the analytical framework of the paper was streamlined along with these topics of research interest contextualized to relevant stages of manufacturing dynamics.

\section{Industrialization as the way to economic modernization during communism}

After World War II, centrally planned industrialization characterized urban and regional development (Ronnâs, 1984). Forceful industrialization alongside agriculture collectivization fostered the labour transfer from the primary to the secondary sector, especially towards the heavy manufacturing industry. The regional policy, subordinated to sectoral planning, led to the concentration of manufacturing activities in urban centres where the competition for resources was undermined by centralized decision making and channelling of investments, both strongly influenced by the administrative divisions. The emphasis on secondary activities triggered their dominant position in the economic base of urban economies, more than the urbanization scale would have suggested, with services holding a secondary position (Popescu, 2014).

Industrial policy has gradually addressed the different layers of the urban system. During the 1950-1960 decade, the regional cities with a large share of population and leading role within the administrative layout of the national territory have been strengthen by significant investments and rural to urban transfers of labour. The 1968 territorial administrative reform placed the county seats at the centre of industrialization. The old county seats received additional investments to capitalize on their existing industrial activities and diversify into new ones. This dramatic increase was recorded by the new county seats where the location of industrial activities aimed at strengthening their economic power and leading role as administrative units (Popescu, 2014). Under the principle of territorial balanced development aiming at reducing the inter-regional gaps, the industrial policy targeted the small towns and the countryside starting with the mid-1970s. Additionally, the River Danube and Sea-Front Industrialization 
Program brought less developed regions into the spotlight of the planning policy. The focus on the development of large scale industrial plants across all levels of urban system resulted in a growing number of mono-industrial centres and onecompany towns.

Territorially, the emergence of 41 counties designed to become socioeconomic entities had a strong effect on the economic organization at regional and national levels. Groza (1999) points to the role of counties as territorial envelopes of urban and industrial development where the bottom layers of the urban system gravitated around the county capitals. The model of economic organization based on industrial activities and the county-based territorial cells provided incentives for territorial fragmentation and administrative competition. The consequences were many-folded: the rural to urban migration flows influenced the distribution patterns of population and labour; the overemphasis of production activities limited the scope of urban economies to provide an extensive range of services in line with the demographic size; and last, but not least the gaps between urban and rural have been strengthened along with strong dependence relationships. As a result of this longstanding regional and economic policy, at the end of communism, there were seven secondary cities with around 300,000 inhabitants each despite efforts to divert migration flows from regional cities to new county seats and small and medium-sized towns. As a result of banning migration to the large cities, new county seats such as Zalău and Vaslui artificially doubled their population in less than 15 years (Cristea et al., 2017). This rapid expansion requested a considerable amount of investments, mainly towards industrial activities. The plan for further industrialization-biased urbanization aimed at enlarging the number of urban centres to 550-650 in 2000 (Dumitrescu, 2008). The last step taken in this direction was in the late 1980s when the number of towns grew from 236 to 260 as an anticipation of their prospects of future development rather than a recognition of past performance.

From a sectoral perspective, the emphasis of industrialization relied on heavy industries and the underlying dominance of productive activities over tertiary activities. The economic power of Romania was founded on industry as the primary contributor to GDP creation, with a share of $58 \%$ in the national wealth creation against $15 \%$ coming from agriculture (Anghelache et al., 2018). The most important industrial sectors in terms of output and employment were machine building, metallurgy, chemical, construction materials, oil processing. Others added to this many-sided industrialization, such as textiles and ready-mades, wood processing, leather and footwear, and the food industry in order to meet the needs of the national economy and society while reducing the imports.

\section{Deindustrialization in the 1990s}

In 1990 the national economy was dominated by manufacturing employment accounting for $42.3 \%$ of the national total. The post-1990 restructuring of the economy was accomplished by shrinking the oversized socialist industrial sector 
clustered mainly in urban areas. The number of industrial jobs declined dramatically by 53.83\%, from 3,451,507 in 1990 to $1,593,392$ in 2002. Consequently, the rate of industrialization declined from $42.3 \%$ in 1990 to $34.8 \%$ in 2002. Cross-country analyses of the economic restructuring across Central and Eastern Europe (CEE) rank Romania on the top position in terms of industrial employment losses during the first decade of the transition. As noticed by Maniu et al. (2001), the loss of industrial employment was matched by an increase in the employment share of the agricultural sector as labour resources have moved from industry to agriculture and the reversal of the agriculture and industry shares in total employment due to the concomitant processes of deindustrialization and reagrarization (Trăistaru \& Wolff, 2002). Changes in institutional arrangements and political decisions regarding power decentralization, unpredictable relationships between privatization and economic restructuring (Popescu, 2020), and growing inequalities at inter and intra-regional scale (Benedek, 2015) determined the context that defined the post-1990 socioeconomic transformation of Romania.

Urban areas of all demographic sizes had to cope with deindustrialization. In 1992, 122 out of 260 cities and towns had an above-average location quotient of industrial employment, and about 5 million urban dwellers were subject to forthcoming deindustrialization (Popescu, 2014). Large cities recorded a strong shift of employment between industry and services where the drop of manufacturing was partially recovered by slowly increasing tertiary activities. The surplus of labour layoffs determined soaring unemployment and poverty rates alongside growing costs to afford urban life. However, the most hit by deindustrialization were the small, mono-industrial and one-company towns suffering from de-economization (Bănică et al., 2013), i.e. the loss of labour market and supply urban functions. Urban shrinkage, the back to the village movements and international migration flows reflected the process of desurbanization and narrowed further opportunities for the development of this category of towns (Popescu, 2020).

Substantial socio-economic disruptions had important consequences on the role of each category of urban centres within the national economy. Overall, the number of mono-industrial towns decreased dramatically to 51 in 2002 (Dumitrescu, 2008). Most of them (33) were specialized in a wide range of manufacturing sectors, such as metallurgy, chemical, machine-building, construction materials, wood processing, textile and ready-mades, and food industry. To these, 18 mining towns were added; in this case, the shock reform enacted in 1997 with a loss of about 100,000 jobs in a short span of time (late 1997 and early 1998) aggravated the social and economic negative effects of industrial restructuring. However, there were also signs of reindustrialization based either on domestic entrepreneurship or foreign direct investments. Thus, notwithstanding the growing number of industrial firms, reaching 47,582 in 2002 , the impact on rebalancing the local labour markets and urban economies was limited. The transformation of the industrial sector during the first decade of transition was not specific only to Romania but to the majority of CEE countries. 
The process is rooted in the crisis of the socialist industry during the 1970s (Lux, 2017) manifested in the emergence of parallel industrial structures, isolation from competitive pressures and innovation flows and nonmarket rationality, overspecialization and low institutional capacity to adapt to a changing environment. The socio-economic transformations turned the region into a pole of urban shrinkage due to the reverse migration away from the former industrial centres that had gone into bankruptcy (Popescu, 2014). The scale of urban shrinkage points to the limited capacity of local and regional economies to diversify and support spillovers. It is demonstrated that economic diversification is closely related to the current production structures; therefore, the recovery of the economy through sectoral related diversification should be approached in conjunction with other major processes, among which deindustrialization, skillbiased technological change, job polarization, and urbanization to influence the regional growth, requesting an increased role for policy and entrepreneurship to support unrelated diversification (Holm \& Østergaard, 2018). Consequently, there are many structural barriers to economic development, especially in CEE regions having to cope with fast and profound institutional changes and inherited industrial structures (Szakálné Kanó et al., 2019).

\section{From economic rebound to economic decline and back in the 2000s}

The exit from the 1990s industrial crisis started in early 2000 with the rebound of the national economy. Deindustrialization slowed down, and reindustrialization prompted new growth dynamics mainly in core regions characterized by large scale urbanization, proximity to the EU economic gravitational centre, accessibility and the availability of in-demand skills. Nevertheless, this period shows a high degree of instability with ups and downs reflected in the pathways taken by employment, firms, and industries. As such, the period should be split into three successive sub-periods: the rebound from 2002 to 2008; the global economic crisis from 2008 to 2012; and the latest rebound from 2012 to 2019 . However, the industrialization rate of $23.1 \%$ in 2019 , half of the value recorded in 1990, is illustrative of the scale and scope of structural changes of the Romanian industry.

Within the recovery stage of the national economy before the onset of the crisis, the structural adjustments of industrial activities continued. The disjunction between the positive evolution of firms and the negative evolution of employment is argumentative in this respect. The "employment deindustrialization" is a common feature identified in many transition economies across the CEE region (Borgersen and King, 2016:520). On one side, the decline of employment mirrors the positive effects of technological changes and subsequent productivity improvements; on the other side, the increasing number of industrial firms suggests that manufacturing supports the expansion of production activities while providing reliable incomes. These trends endorse the view that a large manufacturing sector increases the chances for better living conditions of citizens 
and a country's international leverage (Aiginger \& Rodrik, 2020), especially in CEE countries where income growth has relied on manufacturing sectors (Bolea et al., 2018). However, we notice that during 2012 and 2019, both manufacturing firms and employment recorded positive growth rates $(16.3 \%$ and $12.1 \%$, respectively), indicating the potential of industries to generate jobs. At the same time, the breakdown of firms by size shows the dominant position of micro and small and medium-sized firms with limited contribution to the overall growth and high vulnerability to internal and external changes.

Although there is strong evidence of growing regional specialization and geographic concentration of industrial activities during the first decade of the transition (Trăistaru et al., 2002), the continued deindustrialization along the 2002-2012 period and the dynamic interplay between secondary and tertiary sectors materialized in the further decline of industrial specialization of urban economies. The number of industrial towns decreased by $85.9 \%$ between 1990 and 2017, totalizing 28 industrial towns (Popescu, 2020). Significant changes have occurred at the regional level as well. Regions with large scale urbanization, high shares of skilled labour and a favourable local environment for business and innovation are the winners of the current competitive framework of industrial transformation (Bucharest, Cluj, Iași, Constanța). At the other end of the spectrum, old industrial and peripheral regions with dominant industries in contraction, lower accessibility and attraction for FDI find it difficult to cope with these liabilities and engage in growth trajectories (Botoșani, Vaslui, Gorj, Teleorman).

\section{Industrial change and economic growth}

Romania is a middle-income country with a GDP/capita of 12,896 current US\$ in 2020 (World Bank, 2020) lower than in Hungary, the Czech Republic and Poland and higher than in Bulgaria. With a drop of $39 \%$ during the 1990 s, the values of GDP/capita recorded a nine times growth after the early 2000s within the context of the rebound of the national economy. Despite the inter- and intra-industrial changes, the industry share in GDP creation was relatively unchanged, with $24.8 \%$ in 2002 and $23.2 \%$ in 2019. Within this period, there are significant variations determined by the 2008 economic crisis and recovery afterwards. However, a decreasing trend is noticed over the 2013-2019 period (Figure 1).

Industry, as a major determinant of EU convergence, impacted the territorial economic organization through internal divergence. According to the World Development Report 2009: Reshaping Economic Geography (WDR'09), the development gap between the most dynamic regions in Romania (the leading regions) and the less developed regions (the lagging regions) has widened. Among the first category, Bucharest and Ilfov county (de facto the suburb of the capital city) stand out as the most economically dynamic regions (Ionescu-Heroiu et al., 2013). Bucharest, especially, features as the most powerful economic engine both at the national and EU level with GDP/capita values higher than the EU average. 


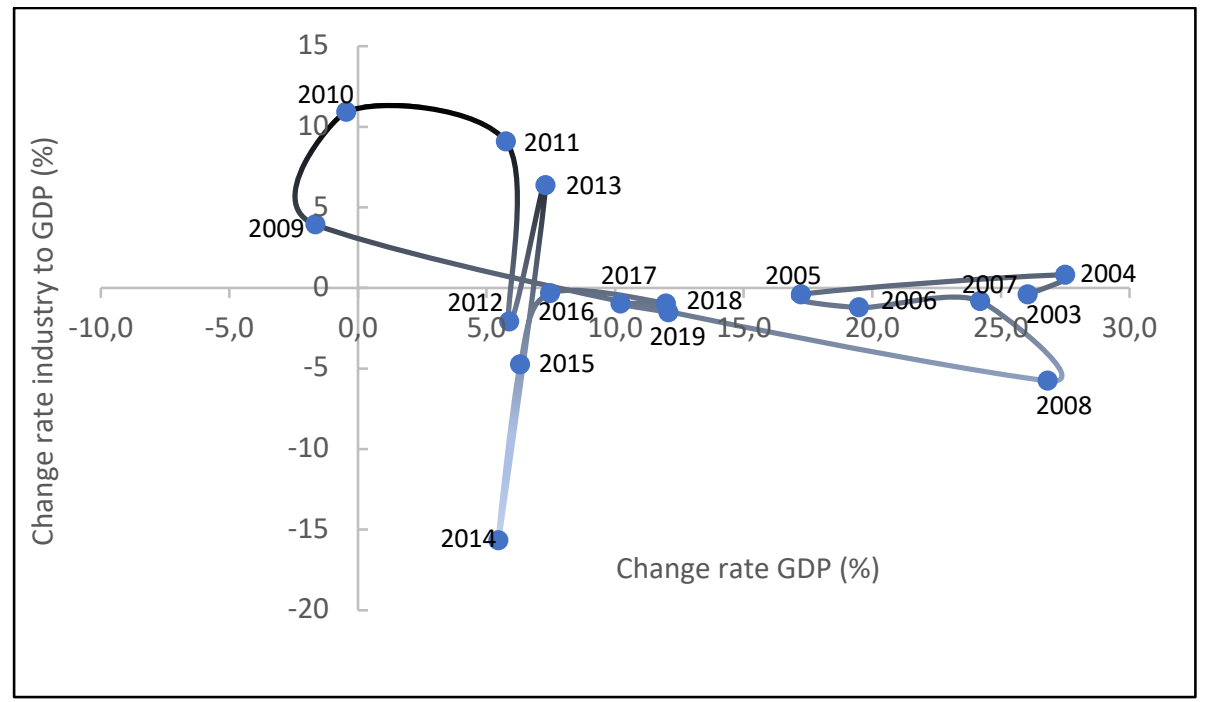

Figure 1. Yearly change rates of GDP total and industry share to GDP creation Source: National Institute of Statistics Tempo online data series; by the author

However, recent evidence points to the higher growth rates of secondary cities, such as Cluj Napoca, Iași, Timișoara, Constanța as compared to Bucharest that suggests a catching-up process and expansion of economic growth towards regional poles (Cristea et al., 2017).

All along the 2000s, most counties except for some in the south and east of the country, recorded a higher share of the EU's GDP in 2009 compared to 1995. The lagging regions in Romania have been among the fastest-growing regions in the EU. Notwithstanding, the development gaps remained significant at the regional level: the Bucharest-Ilfov region exceeds the EU average by $30 \%$, whereas the least developed region in Romania and one of the poorest in EU, the North-East region, reaches only $30 \%$ of the EU average. Development studies argue that divergence is a typical characteristic in the early stages of growth, mainly as a result of regional specialization and geographic concentration of industrial activities. The industrial activities clustered in core regions stir spillover effects supporting further convergence in the long run.

\section{Exogenously-led growth of manufacturing}

There is wide recognition of the role direct foreign investments play in the post1990 development of CEE countries in terms of economic growth, productivity improvement, and integration in the global supply chains. The bright side of international investment inflows is highlighted by the formative role of FDI in transition economies where domestic firms benefit from being agglomerated with technologically related foreign firms (Szakálné Kanó et al., 2019). The knowledge and technology transfer is central to the modernization of regional economies, especially because, as Boschma and Capone (2016) maintain, Eastern European countries, as compared with Western European ones, tend to diversify into new industries that are more closely related to their existing industries. In any case, 
competitiveness improvements result from both related and unrelated variety of industrial activities. Hence, the regional economies with low endogenous potential for growth need exogenous factors, such as FDI and policy-induced changes to embark on new development trajectories. Conversely, there is also a dark side of FDI impact on CEE economies. First, CEE economies developed as dependent market economies relying on international value chains and multinational corporations as vehicles for regional economic development (Nölke \& Vliegenthart, 2009; Lengyel \& Leydesdorff, 2015). In times of economic downturn, as the 2008 crisis, the CEE economies were more hit in comparison with their western counterparts due to the increased vulnerability and exposure to demand changes at the international level. Second, empirical studies demonstrate that the linkages between domestic and foreign-owned firms could have either positive or negative consequences. Pavlínek (2017) differentiates between developmental linkages and dependent linkages. The former foster functional upgrading and higher value-added functions, while the latter hamper the knowledge and technology transfer and position domestic firms in captive production networks.

Figure 2 depicts the evolution of FDI total and FDI in manufacturing (in terms of capital invested). The change rates of both variables are positive throughout the period 2002-2019. The dynamics are strikingly varying from very high growth rates at the beginning of the 2000s and very low in the rest of the period. Analyzing the FDI patterns and dynamics in Romania, Zaman \& Vasile (2012) distinguish several stages: sustained growth between 2003-2006 when the FDI recorded a four times increase of invested capital within the context of mass privatization of the banking and manufacturing sectors, in particular oil and petro-chemistry, steel industry and machine building; the peak of international investments in 2008 in the banking sector, utilities and energy industry; a sharp decline in 2009-2010 as a result of the crisis.

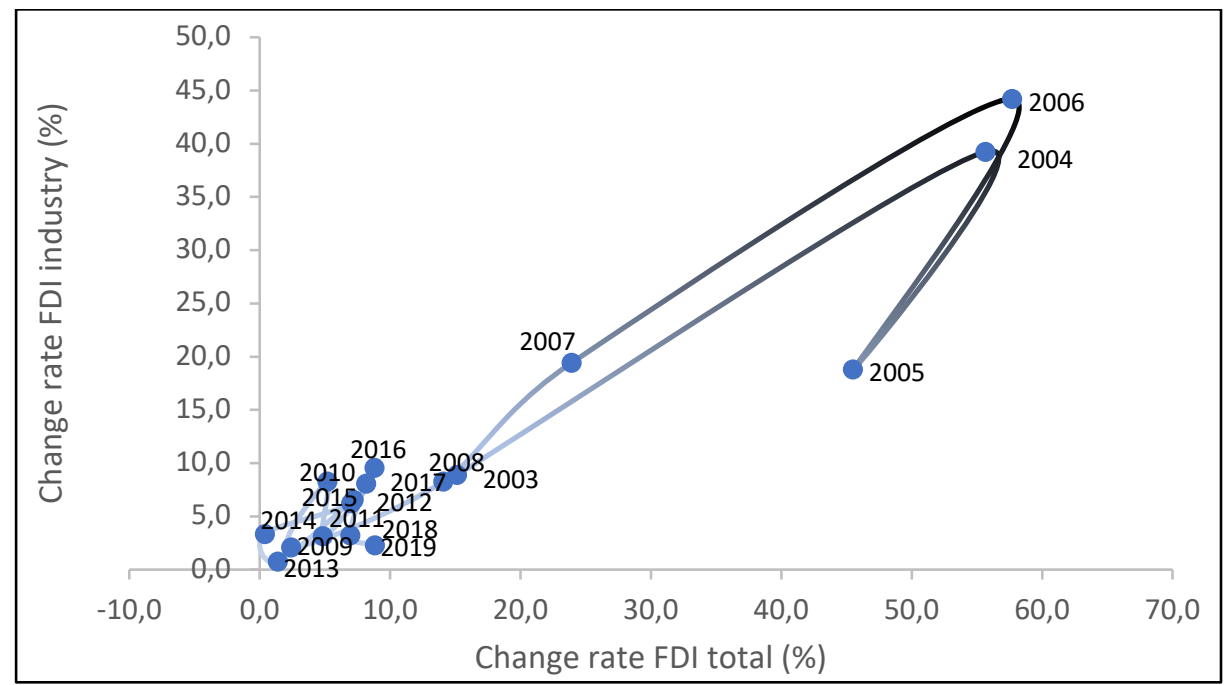

Figure 2. Yearly change rates of FDI and industry share to FDI total Source: National Institute of Statistics Tempo online data series; by the author 
If the modest growth rates in the late 2000 s are explained in relation to the economic crisis, the persistent low values all along the 2010s within the context of economic rebound are problematic. This evolution trend is connected, at least partially, with the declining share of manufacturing FDI from $62.9 \%$ in 2002 to $29 \%$ in 2019. Another interesting finding revealed by the graphic is that the biggest amounts of capital have been invested in the period prior to Romania's accession to the EU; after 2008, the total and manufacturing investment inflows decreased dramatically with the onset of the crisis but continued along the same pathway after 2010 despite the rebound of the economy.

The FDI strengthened the role of the manufacturing sector in various ways, among which the increasing trade flows of industrial products hold a relevant significance. The shift from low competitive manufacturing sectors developed in the communist period such as metallurgy, machine building or ready-mades to transportation means, electronic and electrical equipment supported a more robust export performance materialized in eight times higher exports in 2014 than in 1990 (Cristea et al., 2017). Almost three-quarters of the EU exports are represented by transportation means, electronic devices and chemical products; this breakdown of exports suggests the shift from low to high technology products. At the same time, the FDI location strategy contributed to the widening of regional inequalities. Dogaru et al. (2015) find that in Romania and other CEE countries, the capital city regions receive higher investment inflows in various sectors and functions. The spatial patterns of FDI in Romania point to the concentration of foreign investments in large cities, in particular Bucharest, but also some others (Timișoara, Cluj Napoca, Pitești, Craiova), in western regions and the Black Sea port of Constanța more likely to host higher-end sectors and functions.

\section{Employment deindustrialization}

The decline of industrial employment in Romania is one of the highest among CEE countries. This can be explained by the firm reliance of the national economy on the industry during communist times and the profound transformations of the industrial sector in the aftermath of the regime change in 1990. The former reflects the occupational disadvantage commonly found in old industrial regions that limits the capacity to adapt to economic change (Dawley et al., 2014). The latter points to the structural changes of the industrial sector to enable productivity and competitiveness gains. A common feature of the transition economies refers to the constant employment deindustrialization as a reflection of the specificity of industrial sectors and economy-wide characteristics (Borgersen and King, 2016).

The evolution of the total and manufacturing employment based on the yearly change rates (Figure 3) mirrors the trajectories followed in very different contexts of growth and decline. The early 2000s are characterized by divergent pathways of total and industrial employment due to the decline of employment in industrial activities and the increase of total employment. This suggests the shift of labour from the secondary sector to primary and tertiary sectors. 


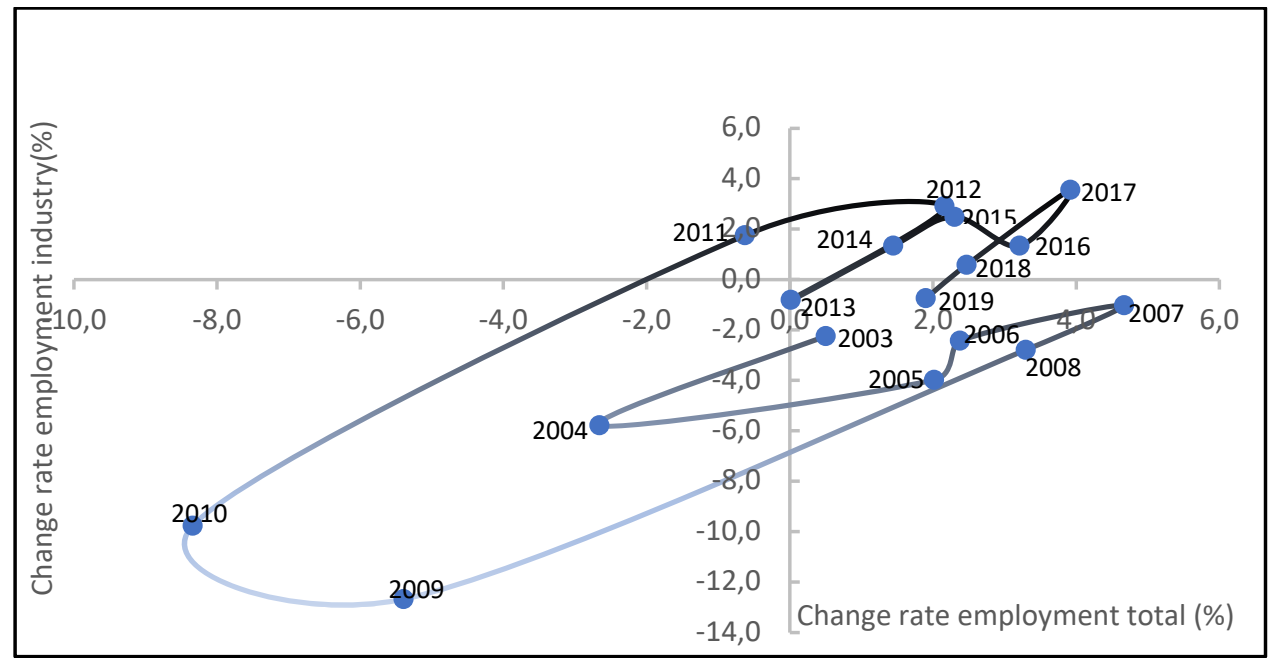

Figure 3. Yearly change rates of total and industrial employment

Source: National Institute of Statistics Tempo online data series; by the author

The effects of the 2008-2010 crisis on both variables are sharp, with significant downturns. After 2011, the national economy bounced back rapidly, and significant increases were recorded by total and industrial employment. By the end of the period, a slight decrease is again noticeable, possibly to be continued under the pandemic context of 2020. Over the period, employment in manufacturing continued to drop by 25.1\% (from 1,593,392 in 2002 to 1,192,979 in 2019).

Manufacturing sectors have evolved along divergent trajectories between 2002 and 2019, influencing the overall evolutionary trends. Almost all industrial sectors declined in terms of employment except for the road transport industry that grew significantly due to major FDI in automotive, for example, Renault-Dacia and Ford Romania, and the supplier networks developed around them. For the rest of the industrial sectors, we notice declining trends, either strong with more than $50 \%$ job losses (tobacco, textiles, oil processing and coal coking, chemical products, non-metallic products, metallurgy, machinery and equipments) or moderate with less than $50 \%$ job losses (food and beverages, clothing, leather and footwear, wood processing, rubber and plastics, computer, electronic and optical products, furniture). No consistent correlation can be made, looking at the declining industries and their technology level as industries with low, medium and high technology took similar pathways of employment evolution.

In spatial terms, the distribution patterns of industrial employment have changed. In particular, labour mobility and commuting have downsized and reshaped. Industrial poles with foreign investments attract labour in mediumhigh and high sectors (automotive, computers and electronics) while other industrial centres where resource-based and labour-intensive industries prevail attract less skilled workforce with below-average wages (Cristea et al., 2017). The high-paying sectors are concentrated in few large cities, such as Bucharest, Cluj Napoca, Timișoara, Brașov, Galați (Ionescu-Heroiu et al., 2013). Despite the 
strong decline in the last three decades, the industrial sector remained the main employer, but its contribution to wellbeing provision has dramatically reduced.

\section{Manufacturing firms on the rise}

In contradiction with the sharp decline of employment, industrial firms rose by 15.3\% between 2002 and 2019 (from 47,582 to 54,972) as a combined result of domestic entrepreneurship and foreign direct investments. The breakdown of industrial firms by size reveals the over-representation of small and medium-sized enterprises (SMEs) with less than 249 employees, accounting for $97.4 \%$ in 2002 and $98.6 \%$ in 2019. Out of these, a high share is recorded by micro-enterprises (0-9 employees), showing the dominance of very small-sized firms, typically associated with low levels of innovation and high exposure to contextual and structural changes. Their vulnerability is even more enhanced when located in peripheral regions where firm performance depends on knowledge spillovers, dynamic local economy and access to skilled labour (Grillitsch \& Nilsson, 2017). Based on a cross-country analysis, Trippl et al. (2020) identify the less developed regions in CEE regions, among which the North-East region in Romania. This study argues that in these regions SMEs with poor innovation capabilities and externally controlled multinational enterprises less concerned with regional development are prevalent. Moreover, the poor linkages with universities and research organizations, public authorities and intermediate actors are unsupportive for firm performance enhancement.

The same pattern of successive stages of growth and decline are identified when analysing the evolution at firm level in the national economy and manufacturing (Figure 4). The crisis of 2008-2010 interrupted the increasing trends of the early 2000 and the 2010 s.

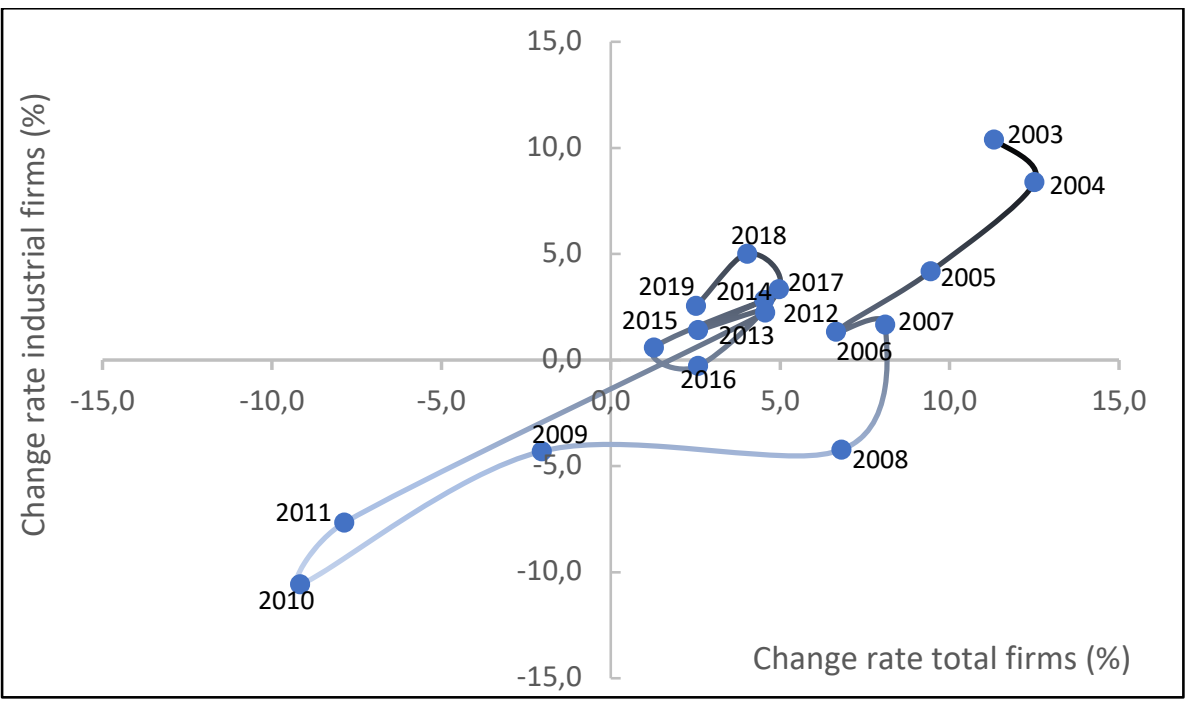

Figure 4. Yearly change rates of total and industrial firms

Source: National Institute of Statistics Tempo online data series; by the author 
Besides the turning points in the evolution of firms, there were important changes in the geographical concentration and regional specialization. Firms in certain industries, such as IT, tended to agglomerate in regions where access to a qualified pool of labour, reliable suppliers, and shared knowledge and innovation existed (Ionescu-Heroiu et al., 2013). Therefore, regions display varying assets and firms located in those favoured by a higher density of labour and accessibility and diversified economic base. As a result, some regions specialized in higher value-added industrial sectors, while others remained captive in their inherited specializations.

\section{Changing spatial patterns}

Structural changes of industry translated into the significantly different spatial distribution of production activities. Deindustrialization, sub-urbanization and urban outmigration are evidenced as the key processes that explain the spatial patterns of socioeconomic restructuring (Dumitrache et al., 2016; Török \& Benedek, 2018). The consequences refer to increasing spatial inequalities (Popescu, 2014) and the widening of gaps between cores and peripheries at the regional scale (Benedek, 2015). The growing internal divergence is evidenced by Cutrini (2018), who, in cross-country study at EU level, found that the Romanian regions belong to different clusters: metropolitan areas and capital regions (Bucharest-Ilfov), the central European manufacturing core (West, Center and South-East) and deindustrializing regions with intermediate average per capita income levels (North-West, North-East, South and South-West) and show the cumulative causation of agglomeration processes and the mix of industrialization and high-tech services specialization. Some studies argue that regional policy failed to achieve the goal of reducing regional disparities, and focusing on urban growth poles intensified the regional imbalances (Benedek, 2016).

Additionally, the core-periphery inequalities strengthened. That is explained by the role of Bucharest as a primate city in conjunction with the increasing weight of secondary cities in the urban and economic dynamics. The 8 largest cities in Romania (Iași, Cluj, Timișoara, Brașov, Ploiești, Craiova, Bucharest, Constanța) concentrate almost a quarter of the population and create more than $50 \%$ of the national GDP (Ionescu-Heroiu et al., 2013). This study points to the changes triggered by deindustrialization and reindustrialization processes taking a macrospatial focus on the distribution patterns of industrial employment and firms. It is noticeable that the industrial axis of 1990 stretching from SE-Center-NW moved to Center-West regions in 2019, reflecting the relatively decreasing role of urbanization economies in favour of locational factors. This study is consistent with the findings of Ionescu-Heroiu et al. (2013) and Cristea et al. (2017) that the leading regions are: Bucharest-Ilfov, with its sizeable economic mass and gravitational pull; the Western region closer to EU markets and crossed by major trade flows; the Center region, with a dynamic industrial base; and Constanța, with the largest port on the Black Sea and the fourth largest in Europe. 


\section{Conclusions}

Compared to Western European countries, Romania, in concert with some other CEE countries, passed through structural changes and regional relocation of industries that strengthened the concentration and specialization externalities (Trăistaru et al., 2002). The above-average relative size of the manufacturing sector holds a positive significance for the EU convergence process (Goecke \& Hüther, 2016). However, the one-size-fits-all policy of the EU should take account of the divergent trends between Western Europe more oriented to the diversification of industries and services and Eastern Europe more likely to foster specialized industrial agglomerations (Marroccu et al., 2010).

In Romania, industry has been transformed, and the scale and pace of change have reshaped the national economy and reconfigured the fabric of many industrial regions. All industries have been affected by the process of restructuring, and location played a formative role in the process of adjustment. A powerful driver of counter and sub-urbanization (Popescu, 2020) and migration flows, the regional industrial restructuring generated growing economic polarization and inequalities. Growing disparities in income and work opportunities emerged due to national and international economic forces and the adjustment of industries and services to shape future specializations. The changes discussed above are typical of the economic restructuring with regions and urban centres experiencing a dramatic change in their economic roles and functions and rising inequalities between metropolitan and non-core regions.

The paper also points to the regional policy challenged by the overly focus on large urban agglomerations and the need to balance the development opportunities among the various levels of the urban system and to enforce the integration of industrial activities along with production networks. This will be beneficial for knowledge and technology spillovers from large dynamic cities to small, vulnerable towns, as well as from core regions to peripheral backward regions. In other words, the study argues that the shift from urban to territory would contribute to pursuing a sustainable and cohesive model of socioeconomic development where industrial activities play a central role.

\section{References}

Aiginger, K. and Rodrik, D. (2020), "Rebirth of Industrial Policy and an Agenda for the Twenty-First Century", Journal of Industry, Competition and Trade, vol. 20, p. 189-207.

Anghelache, C., Anghel, M.G. and Badiu, A. (2018), "Repere ale evolutiei industriei romanesti, Revista / Journal „ECONOMICA”, no. 2, vol. 104, p. 62-80.

Banica, A., Istrate, M. and Tudora, D. (2013), "(N)ever becoming urban? The crisis of Romania's small towns" in A. Fischer-Tahir \& M. Naumann (eds.), Peripheralization, Springer VS, Wiesbaden, p. 283-301. 
Benedek, J. (2015), "Spatial differentiation and core-periphery structures in Romania", Eastern Journal of European Studies, vol. 6, no. 1, p. 49-61.

Benedek, J. (2016), "The role of urban growth poles in regional policy: the Romanian case", Procedia - Social and Behavioral Sciences, vol. 223, p. 285-290, $2^{\text {nd }}$ International Symposium, Reggio Calabria Italy.

Bolea, L., Duarte, R. and Sánchez Chóliz, J. (2018), "From convergence to divergence? Some new insights into the evolution of the European Union", Structural Change and Economic Dynamics, vol. 47, p. 82-95.

Boschma, R. and Capone, G. (2016), "Relatedness and diversification in the European Union (EU-27) and European Neighbourhood Policy countries", Environment and Planning C: Politics and Space, vol. 34, no. 4, p. 617-637.

Boschma, R. and Frenken, K. (2011), "Technological relatedness, related variety and economic geography" in P., Cooke, B., Asheim, R., Boschma, R., Martin, D., Schwartz and F. Todtling (eds) Handbook of Regional Innovation and Growth, Edward Elgar, Cheltenham UK.

Borgersen, T.-A. and King, R.M. (2016), "Industrial structure and jobless growth in transition economies", Post-Communist Economies, vol. 28, no. 4, p. 520-536.

Burger, A., Damijan, J.P., Kostevc, Č. and Rojec, M. (2017), "Determinants of firm performance and growth during economic recession: The case of Central and Eastern European countries", Economic Systems, vol. 41, no. 4, p. 569-590.

Capasso, M., Cefis, E. and Frenken, K. (2016), "Spatial differentiation in industrial dynamics. The case of the Netherlands (1994-2005)", Tijdschrift voor Economische en Sociale Geografie (TESG), vol. 107, no. 3, p. 316-330.

Capello, R. and Perucca, G. (2015), "Openness to Globalization and Regional Growth Patterns in CEE Countries: From the EU Accession to the Economic Crisis", Journal of Common Market Studies, vol. 53, no. 2, p. 218-236.

Capello, R. and Perucca, G. (2017), "Industrial restructuring in CEE regions: determinants of regional growth in the accession and in the crisis period", Journal of Baltic Studies, vol. 48, no. 3, p. 309-329.

Cristea, M., Mare, C., Moldovan, C., Chia, A., Farole, T., Vințan, A, Park, J., Garrett, K.P. and Ionescu-Heroiu, M. (2017), Magnet cities, migration and commuting in Romania, World Bank Group, Bucharest.

Cutrini, E. (2018), "Economic integration, structural change and uneven development in the European Union", ERSA $58^{\text {th }}$ Congress Places for People: Innovative, Inclusive and Liveable Regions, Cork, Ireland August $28^{\text {th }}-31^{\text {st }}$.

Davies, B. and Maré, D.C. (2021), "Relatedness, complexity and local growth", Regional Studies, vol. 55, no. 3, p. 479-494.

Dax, T. and Fischer, M. (2018), "An alternative policy approach to rural development in regions facing population decline", European Planning Studies, vol. 26, no. 2, p. 297-315.

Dawley, S., Marshall, N., Pike, A., Pollard, J. and Tomaney, J. (2014), "Continuity and Evolution in an Old Industrial Region: The Labour Market Dynamics of the Rise and Fall of Northern Rock", Regional Studies, vol. 48, no. 1, p. 154-172.

Dogaru, T., Burger, M., Karreman, B. and van Oort, F. (2015), "Functional and Sectoral Division of Labour within Central and Eastern European Countries: 
Evidence from Greenfield FDI", Tijdscrift economische en sociale geografie, vol. 106, no. 1.

Dumitrache, L., Zamfir, D., Nae, M., Simion, G., and Stoica, I.V. (2016), "The urban nexus: Contradictions and dilemmas of (post)communist (sub)urbanisation in Romania", Human Geographies - Journal of Studies and Research in Human Geography, vol. 10, no. 1, p. 39-58.

Dumitrescu, B. (2008), Orașele monoindustriale din România, între industrializare fortată și declin economic, Editura Universitară, Bucharest.

Ferreira, J.J., Farinha, L., Rutten, R. and Asheim, B. (2021), "Smart Specialisation and learning regions as a competitive strategy for less developed regions", Regional Studies, vol. 55, no. 3, p. 373-376.

Frenken, K., Cefis, E. and Stam, E. (2015), "Industrial Dynamics and Clusters: A Survey", Regional Studies, vol. 49, no. 1, p. 10-27.

Glaeser, E., Kallal, H.D., Scheinkman, J.A. and Shleifer, A. (1992), "Growth in cities", Journal of Political Economy, vol. 100, no. 6, p. 1126-1152.

Golubchikov, O. (2016), "The urbanization of transition: ideology and the urban experience", Eurasian Geography and Economics, vol. 57, no. 4-5, p. 607-623.

Grillitsch, M. and Nilsson, M. (2017), "Firm performance in the periphery: on the relation between firm-internal knowledge and local knowledge spillovers", Regional Studies, vol. 51, no. 8, p. 1219-1231.

Grillitsch, M. (2019), "Following or breaking regional development paths: on the role and capability of the innovative entrepreneur", Regional Studies, vol. 53, no. 5, p. 681-691.

Groza, O. (1999-2000), "Polarisation territoriale et organization administrative en Roumanie. Le chaînon manquant: le niveau regional", Revue Roumaine de Geographie, vol. 43-44, p. 19-34.

Hartmann, D., Zagato, L., Gala, P. and Pinheiro, F.L. (2021), "Why did some countries catch-up, while others got stuck in the middle? Stages of productive sophistication and smart industrial policies", Structural Change and Economic Dynamics, vol. 58, p. 1-13.

Hassink, R. and Gong, H. (2019), "Six critical questions about smart specialization", European Planning Studies, vol. 27, no. 10, p. 2049-2065.

Holm, J.R. and Østergaard, C.R. (2018), "The high importance of deindustrialization and job polarization for regional diversification", Papers in Evolutionary Economic Geography, Utrecht University Urban and Regional research centre, Utrecht.

Ionescu-Heroiu, M., Burduja, S.I., Sandu, D., Cojocaru, S., Blankespoor, B., Iorga, E., Moretti, E., Moldovan, C., Man, T., Rus, R. and van der Weide, R. (2013), Romania competitive cities: Reshaping the economic geography of Romania, World Bank Group, Washington, DC.

Kinossian, N. (2018), "Planning strategies and practices in non-core regions: a critical response", European Planning Studies, vol., 26, no. 2, p. 365-375.

Küpper, P., Kundolf, S., Mettenberger, T. and Tuitjer, G. (2018), "Rural regeneration strategies for declining regions: trade-off between novelty and practicability", European Planning Studies, vol. 26, no. 2, p. 229-255. 
Květoň, V. and Šafr, K. (2019), "Regional embeddedness, relatedness and interregional linkages among less developed regions in Central Europe", European Planning Studies, vol. 27, no. 5, p. 862-884.

Lagendijk, A., van der Velde, M. and Kuijpers, M. (2020), "Looking for causes of effects in cases: Evaluating intermunicipal collaboration in the Netherlands applying QCA", Zeitschrift für Wirtschaftsgeographie.

Leick, B. and Lang, T. (2018), "Re-thinking non-core regions: Planning strategies and practices beyond growth", European Planning Studies, vol. 26, no. 2, p. 213 228.

Lengyel, B. and Leydesdorff, L. (2015), "The Effects of FDI on Innovation Systems in Hungarian Regions: Where is the Synergy Generated?", Regional Statistics, vol. 1, p. 3-24.

Lux, G. (2017), "Industrial competitiveness" in G. Lux and H. Gyula (eds) The Routledge Handbook to Regional Development in Central and Eastern Europe, Routledge, p. 29-46.

Maniu, M.T., Kallai, E. and Popa, D. (2001), Explaining growth. Country Report Romania (1990-2000), Global Development Network, 12 May 2021, shorturl.at/alHOW.

Maroccu, E., Paci, R. and Usai, S. (2010), "Productivity Growth in the Old and New Europe: the role of agglomeration economies", Working Papers, vol. 24, CRENoS.

Martinus, K., Suzuki, J. and Bossaghzadeh, S. (2020), "Agglomeration economies, interregional commuting and innovation in the peripheries", Regional Studies, vol. 54, no. 6, p. 776-788.

Murawski, M. (2018), "Actually-Existing Success: Economics, Aesthetics, and the Specificity of (Still-)socialist Urbanism", Comparative Studies in Society and History, vol. 60, no. 4, p. 907-937. Cambridge University Press.

National Bank of Romania (2021), Investiţiile străine directe în România, 20 September 2021, shorturl.at/epMTV.

National Institute of Statistics Tempo online http://www.insse.ro/cms/.

Neffke, F., Henning, S., Boschma, R., Lundquist, K.J. and Olander, L.O. (2008), "Who needs Agglomeration? Varying Agglomeration Externalities and the Industry Life Cycle", Papers in Evolutionary Economic Geography, Utrecht University Urban and Regional research centre, Utrecht.

Negri, A. (2008), Goodbye Mr Socialism: Radical Politics in the 21st Century, London.

Nölke, A. and Vliegenthart, A. (2009), "Enlarging the varieties of capitalism The emergence of dependent market economies in East Central Europe", World Politics, vol. 61, no. 4, p. 670-702.

Pavlínek, P. (2017), Dependent Growth: Foreign Investment and the Development of the Automotive Industry in East-Central Europe, Springer.

Popescu, C. (2014), "Deindustrialisation and urban shrinkage in Romania. What lessons for the spatial policy?", Transylvanian Review of Administrative Sciences, vol. 42E/2014, p. 181-202. 
Popescu, C. (2020), "'Back to the village': the model of urban outmigration in post-communist Romania", European Planning Studies, vol. 91, no. 6, p. 12001218

Raagmaa, G., Nagy, E., Görmar, F. and Lang, T. (2019), "Understanding and going beyond the regional policy paradox: Conceptual contributions to studying socio-spatial polarisation in Europe" in T. Lang and F. Görmar (eds) Regional and local development in times of polarisation, p. 345-367, Palgrave Macmillan, Singapore.

Rapacki, R., Gardawski, J., Czerniak, A., Horbaczewska, B. and Karbowski, A. (2020), "Emerging Varieties of Post-Communist Capitalism in Central and Eastern Europe: Where Do We Stand?", Europe-Asia Studies, p. 1-28.

Ronnâs, P. (1984), "Urbanization in Romania: A Geography of Economic and Social Change Since Independence", PhD thesis Stockholm School of Economics, Stockholm.

Rutten, R. (2020), "Comparing causal logics: A configurational analysis of proximities using simulated data", Zeitschrift für Wirtschaftsgeographie.

Škuflić, L. and Družić, M. (2016), "Deindustrialisation and productivity in the EU", Economic Research-Ekonomska Istraživanja, vol. 29, no. 1, p. 991-1002.

Smętkowski, M. (2018), "The role of exogenous and endogenous factors in the growth of regions in central and eastern Europe: The metropolitan/nonmetropolitan divide in the pre- and post-crisis era", European Planning Studies, vol. 26, no. 2, p. 256-278.

Smith, A. and Timar, J. (2010), "Uneven transformations: Space, economy and society 20 years after the collapse of state socialism", European Urban and Regional Studies, vol. 17, no. 2, p. 115-125.

Stojčić, N. and Aralica, Z. (2018), "(De)industrialisation and lessons for industrial policy in Central and Eastern Europe", Post-Communist Economies, vol. 30, no. 6, p. 713-734,

Szakálné Kanó, I., Lengyel, B., Elekes, Z. and Lengyel, I. (2019), "Agglomeration, foreign firms and firm exit in regions under transition: the increasing importance of related variety in Hungary", European Planning Studies, vol. 27, no. 11, p. 2099-2122.

Török, I. and Benedek, J. (2018), "Spatial Patterns of Local Income Inequalities", Journal of Settlements and Spatial Planning, vol. 9, no. 2, p. 77-91.

Trăistaru, I. and Wolff, G.B. (2002), "Regional specialization and employment dynamics in transition countries", Working Paper B18, Center for European Integration Studies ZEI University of Bonn.

Traistaru, I., Nijkamp, P. and Longhi, L. (2002), "Regional Specialization and Concentration of Industrial Activity in Accession Countries", Working Paper B16, Zentrum für Europäische Integrationsforschung, Rheinische FriedrichWilhelms-Universität Bonn.

Trippl, M., Zukauskaite, E. and Healy, A. (2020), "Shaping smart specialization: the role of place-specific factors in advanced, intermediate and less-developed European regions", Regional Studies, vol. 54, no. 10, p. 1328-1340. 
Zaman, G. and Vasile, V. (2012), "Macroeconomic impact of FDI in Romania", Procedia Economics and Finance, vol. 3, p. 3 - 11.

World Bank (2020), https://data.worldbank.org > indicator > NY.GDP.MKTP.CD World Development Report (2009), Reshaping Economic Geography, Washington DC. 